\title{
Bargaining power and indicators of well- being among brothel-based sex workers in India
}

Article

Accepted Version

Hui, N. (2017) Bargaining power and indicators of well-being among brothel-based sex workers in India. Feminist Economics, 23 (3). pp. 49-76. ISSN 1466-4372 doi: https://doi.org/10.1080/13545701.2017.1315440 Available at https://centaur.reading.ac.uk/70023/

It is advisable to refer to the publisher's version if you intend to cite from the work. See Guidance on citing.

To link to this article DOI: http://dx.doi.org/10.1080/13545701.2017.1315440

Publisher: Taylor \& Francis

All outputs in CentAUR are protected by Intellectual Property Rights law, including copyright law. Copyright and IPR is retained by the creators or other copyright holders. Terms and conditions for use of this material are defined in the End User Agreement.

www.reading.ac.uk/centaur 
Central Archive at the University of Reading

Reading's research outputs online 


\title{
BARGAINING POWER AND INDICATORS OF WELL-BEING \\ AMONG BROTHEL-BASED SEX WORKERS IN INDIA
}

\author{
Neha Hui
}

\begin{abstract}
This study looks at determinants of bargaining power and well-being among women in sex work in India. Drawing on a questionnaire-based field survey of brothel-based sex workers from Delhi and Kolkata carried out between June and December 2013, it uses the capabilities approach to understand individual, occupational, and institutional determinants of bargaining power and well-being. The study considers bargaining power to be a latent, unobservable variable and estimates it using structural equation modeling. Findings indicate that both institutional and occupational factors play significant roles. The study differentiates between objective and subjective bargaining power. Some factors that play a significant role in determining objective bargaining power, such as years spent in sex work and residence in a brothel, may not play a role in determining subjective bargaining power. Conversely, factors such as marital status and caste play a significant role in determining subjective but not objective bargaining power.
\end{abstract}

\section{KEYWORDS}


Bargaining power, well-being, sex work, capabilities approach, India, Structural Equation Model, gendered occupation

JEL Codes: J16, J44

\section{HEADER: BROTHEL-BASED SEX WORKERS IN INDIA}

\section{INTRODUCTION}

This study aims to understand the determinants of bargaining power and consequently, wellbeing of women in sex work in India. Bargaining power is understood here as the capacity of the sex worker to achieve or experience positive well-being outcomes given individual, institutional, and occupational constraints. These well-being outcomes are consequences of the individual's negotiation with other agents inside and outside the trade, including pimps, madams, law enforcers, customers, family members, and partners. The individual's bargaining power determines her ability to negotiate with these agents. Institutional factors, including social and patriarchal structures that result in stigma attached to the work can be expected to affect the individual's bargaining power. Furthermore, occupational constraints resulting from both the legal and social framework within which the industry is situated can also be expected to have an impact. The illegal and illicit nature of the sex trade in much of the world including India results 
in sex workers being forced to work and reside within the brothel setting, pay transactions costs to other agents like pimps and law enforcers, and face constraints on mobility between brothels or out of the industry. In this study, I consider bargaining power to be a latent, unobservable variable and as such, I analyze the impact of this latent variable on the well-being outcomes of sex workers in India. Furthermore, I posit that there may be a difference between the sex worker's actual bargaining power and what she perceives her bargaining power to be. Her actual bargaining power manifests into her actual well-being outcomes, and I call that her "objective bargaining power." This is differentiated from her "subjective bargaining power," which corresponds to what she perceives is her capacity to negotiate and may not match her actual bargaining power.

While the literature on social well-being uses a range of indicators to measure well-being, I confine myself to the capabilities approach interpretation, which defines well-being in terms of “freedom.” This is based on Sen's conceptualization that freedom is viewed "both as primary end and as the principal means of development" (1999: xi). Freedom here is emphasized on "positive freedom" or the "capacity to be and do" (Gasper and van Staveren, 2003: 137) and the person achieves positive well-being when she experiences these positive freedoms (Sen 1985). This, in this paper we do not define well-being either in terms of cognitive evaluations of life, happiness, satisfaction or positive emotions (as done by Clark et al. 2008 and Easterlin 2004) or in terms pf economic or social measures of quality of life (Diener and Suh 1997). This paper interprets well-being in terms of the individual's capacity to live a full positive life, as realized through the achievement of different 'freedoms' that we will discuss later. I furthermore pay attention to the intersectionality of the different roles a sex worker may play in her work and her private spheres. I look at the relationship between the resources that she has command and 
control over - including institutional and occupational entitlements. My underlying argument is that while the sex worker may face physical, psychological, and financial constraints at the level of resources determined by the patriarchal framework within which they work, the final outcome of well-being is also affected by their individual capacity to negotiate - the bargaining ability of the sex worker. This power cannot be observed and may need to be treated as a latent variable.

Mainstream economic literature has historically interpreted well-being in terms of income and consumption, which has been the basis for policy recommendation (Murgai and Ravallion 2005). However, in recent years there has been significant criticism on the narrowness of this approach to understand the overall welfare and happiness of people (Basu 1987; Kahneman and Deaton 2010). In particular, Amartya Sen argued that "[t]he well-being achievement of a person can be seen as an evaluation of the 'well-ness' of the person's state of being (rather than, say, the goodness of her contribution to the country, or her success in achieving her overall goals)," thus arguing for the shift in focus from economic outcomes especially in terms of income to a more holistic approach to well-being seen in terms of capabilities accommodating economic, political, and social capabilities ((1983:8). These capabilities reflect the freedom of a person to lead different types of lives. Freedom is not just the ability to live a life acquiring basic economic, health, and educational needs but additionally being able to live a full social and political life with human functioning. This includes freedom to be able to make one's own decision, to be free from violence, and to have the freedom of mobility. The achievement of these freedoms would depend on not only the personal characteristics and attributes of the individual, but also her interactions within the social, institutional, and occupational settings where she lives and finally, her capacity to negotiate with other agents in these settings. In this study, I try to explore if there 
exists any factors that link these individual, institutional, and occupational variables to the ability to live a life characterized by the freedom embodying the idea of "well-ness" mentioned earlier.

What determines the mapping of resources to the well-being outcomes that an individual faces? I argue that there is a latent, underlying characteristic of the individual, which relates the resources that the individual can access to her interpersonal relationships with others, in the form of the outcome variables. I interpret this underlying latent concept as the "bargaining power," or the capacity of the individual to negotiate her well-being vis-à-vis other agents with whom she interacts as a social, economic being. The problem with such a conceptualization of bargaining power is that it is not observable. I can use a latent construction and estimate the expected value of this latent construction as an indicator of bargaining power. I additionally consider selfreported indicators of bargaining power, which may be given by a person's perception of her ability to negotiate with other agents. Whether her perceived (self-reported) bargaining is equivalent to her actual bargaining (based on observable indicators) is an interesting question. I therefore build two latent bargaining variables, one for objective bargaining outcomes (based on the outcomes, including the indicators of decision making, mobility, agency, and retained earnings) and the other for subjective bargaining outcomes (based on perceived ability to negotiate).

\section{LITERATURE REVIEW}

As mentioned, my interpretation of well-being is based on the capabilities approach that regards, and consequently seeks to measure, well-being as a multidimensional concept (Martinetti 2000). 
Multi-dimensional well-being indices bring into consideration "commodities" or resources (that is, the set of all goods and services available to the individual) and functionings (that is, what an individual can be or do) in the broader set of capabilities, which includes all possible functionings within a range of opportunities from which they can choose (Bérenger and VerdierChouchane 2007). Through its focus on the "full human being," the capabilities approach calls for broad well-being concerns. Being a full human being for the capabilities theorists involves dignity and equality with respect to employment, bodily safety and integrity, basic nutrition, healthcare, education, and political voice (Nussbaum 2001). Consequently, scholarship within this framework analyzes the well-being of individuals involved in particular occupations. Examples include quality rather than quantity of employment (Sehnbruch 2004), respect and recognition within employment (Hill 2001), and dignity in employment (Sen 2001).

Multiple studies have discussed institutional constraints faced by sex workers including stigma (Della Giusta, Di Tommaso, and Strøm 2008), prohibitionist legal framework (Nussbaum 2000; Gangoli and Westmarland 2008; Della Giusta 2010; Scoular 2010), lack of mobility (Day and Ward 2004), transaction costs (Hui 2012), and community value and individual identity (Akerlof and Yellen 1994). Given these institutional factors, studies have looked at negotiation or bargaining within sex work in terms of empowerment. Using cases from Johannesburg, South Africa, Janet Maia Wojcicki and Josephine Malala look at empowerment beyond the ability to make choice but rather "emphasize the micro decision-making that occurs in sex-workers' daily lives and recognize that these are important components of agency," thus stressing that bargaining in sex work occurs beyond the sex worker as "victim" imagery (2001:101). Collective identity and network intervention have been linked to empowerment of individuals involved in 
risky behavior, especially related to sexual services (Campbell and MacPhail 2002 for South Africa; Latkin et al. 2009 for Thailand and USA).

Literature on India indicates that women struggling with nonliteracy, lower social status, and less economic opportunities are especially vulnerable to HIV infection, as sex work may be one of the few options available to them to earn money (Dandona et al. 2005). Furthermore, stigma and discrimination have been noted to be a hindrance to the empowerment of sex workers, resulting in fatalistic expectations that very little can be achieved in terms of community enterprises (Cornish 2006 using data from Kolkata). There is a significant amount of literature from India that identifies the relationship between individual and collective empowerment and a higher level of welfare. For example, Toorjo Ghose et al. (2008) have argued that sex workers in Kolkata report significantly lower rates of HIV infection and higher rates of condom usage as a consequence of community-based organization and advocacy. Broadening the discussion, Kim Blankenship et al. (2010) have looked at the associations between power and condom use among a sample of women sex workers, defining power in terms of collective power, control over work, and economic power in an attempt to create a multidimensional definition of empowerment for women sex workers in Andhra Pradesh, India. While the literature has identified institutional constraints on the well-being of sex workers and discussed issues of empowerment, the measurement of well-being and discussion (and measurement) of bargaining power is relatively new. This may be because bargaining power is not observable and may need to be analyzed as a latent construct. Maria Di Tommaso et al. (2009) have analyzed latent well-being deprivation among women in the Balkan region who are trafficked into sex work using the capabilities approach. However, to our knowledge, no such attempt has been made for the case of India, even though many authors have identified the 
multidimensional nature of bargaining. Furthermore, there has been no attempt to distinguish between what may be an individual's actual bargaining power and what she perceives to be her bargaining power. This study attempts to fill in this gap by building indices of actual and subjective bargaining power using a structural equation model (SEM).

\section{DATA DESCRIPTION}

The present study uses a questionnaire-based field survey of sex workers in two cities of IndiaDelhi NCR (National Capital Region) and Kolkata. ${ }^{1}$ These two cities are respectively the second and third most populous metropolises in India. ${ }^{2}$ Delhi NCR is the political capital of India, and Kolkata is the eastern center of trade and commerce and capital of the state of West Bengal in eastern India. Both the cities attract migrant workers from within the country as well as from neighboring countries and have historically also been centers of sex trade (Bhagat and Mohanty 2009). The urban sex trade in the two cities, however, differs significantly. Kolkata has experienced two decades of intense mobilizing and lobbying for the rights of sex workers by sex workers' collectives and nongovernmental organizations (NGOs), starting with the Sonagachi project in 1992 (Durbar Mahila Samanwaya Committee 1997). Though such lobbying and NGO activities are spreading to other parts of India, they are still in a comparatively nascent stage in Delhi.

The field survey was carried out in Hindi and Bangla, in two areas of Delhi and five areas of Kolkata by the author with the help of research assistants between June and December 2013. ${ }^{3}$ While four of the areas of Kolkata and one area of Delhi were exclusively red light zones, ${ }^{4}$ one 
area each in Kolkata and Delhi served as a residential area for both sex-worker and non-sex worker populations. It is also important to note here that it was observed in both locations that many sex workers resided in the red light areas with their families (that is, with children and partners). In all, 251 women were interviewed, of whom 182 lived and worked in brothels around Kolkata and sixty-nine in Delhi. However, there was often incomplete information on some topics as the respondents chose not to reply to some questions because of the sensitivity of the question or due to time constraint. Hence, some of the results that are presented have a smaller number of observations. The sex workers interviewed were observed to hold different contracts with brothels where they worked. Contracts were usually either split (locally called adhiya ${ }^{5}$ where the sex worker was able to keep fifty percent or less of their earning), independent (sex workers usually retained their earnings but paid a monthly, daily, or per customer rent), or "flying" (whereby they were not bound to any brothel, but would arrive at the brothel each morning and return each evening to their residence elsewhere in the city). Some sex workers also acted as pimps or madams. The sex workers reported a diverse range of rates charged per act depending on attractiveness and age of worker and location and kind of brothel. The lowest rate reported per act was INR 50 while the highest was INR $2,500 .^{6}$ The sampling was done on the basis of snowball technique using resources made available by Kolkata-based NGO Durbar Mahila Samanway Committee. The data gathered constitutes information on various aspects of the lives and work of sex workers, as well as perceptions of stigma, wellbeing, decision making, and bargaining power.

\section{MODEL SPECIFICATION}


This study draws from work by Di Tommaso et al. (2009) on the use of latent variable analysis for unobservable factors determining well-being outcomes. Using data from the Counter Trafficking Module database, Di Tommaso et al. used well-being deprivation as a latent (unobservable) variable that determines freedom of movement, access to medical care, and abuse of women in sex work, and thereby estimate variables that influence well-being. The data they used primarily constitute women who have been trafficked and comprise only 8.5 percent of women who were in the trade by their own choice. The sample in this study is overrepresented in the other direction, as no sex worker in the present sample reported to the interviewers that she would be physically stopped from leaving the trade if she so chooses. This is not because there were no sex workers who faced such circumstances in the areas where the fieldwork was conducted, but because it was not possible for the field investigators to talk to such sex workers. While 23 percent of the present sample was trafficked into the trade, they no longer worked as a bonded sex worker.

This study further differs from that of Di Tommaso et al. in three ways. First, outcome variables included here are decision making, retaining earnings, mobility, and financial agency, while for Di Tommaso et al. the outcome variables are abuse, access to healthcare, and mobility. In this study, there was not sufficient error-free information available to assess the access to healthcare, so I have not been able to include that as an outcome variable. Though I do have information on abuse, it is information on abuse faced by the sex workers in the past, unlike the rest of the variables (including latent bargaining power), which refer to the present. Second, this study interprets the transformation of the set of resources or entitlements to welfare outcomes in terms of bargaining power with the view that sex workers have a certain amount of control over 
their well-being outcomes, but that is limited by their power of negotiation with others in the trade. Finally, this study also distinguishes between objective bargaining power and selfperceived bargaining power.

I will use an SEM to estimate the overall well-being of the individual as the outcome of her unobservable bargaining power. This model allows us to build a system of equations that specifies the relationship between a set of observable exogenous variables (in this case the set of individual and institutional resources available to the sex worker) and a set of endogenous indicator variables (the well-being outcome variables) either directly or via an unobserved or unmeasured latent variable (which I call bargaining power). Figure 1 depicts the underlying relationships in the SEM. The intuitive argument here is that the individual's experiences of her outcome variables (that is, her well-being indicators) are constrained by the individual or external exogenous factors (like age, skills, assets, community networks, among others) not just directly but also via the individual's internal capacity to bargain (in this case the latent variable, bargaining power). Bargaining power is understood to be the capacity of the individual to negotiate with her institutional and occupational circumstances, including other agents in the trade, and translate them into the well-being outcomes she faces. This latent variable is presented in the oval figure while the observed exogenous and endogenous variables are presented in the rectangular figures.

(Figure 1 here, third of a page)

Following Bollen (1987), Karl G. Jöreskog and Arthur S. Goldberger (1975), and Jaya Krishnakumar and A. L. Nager (2008), I specify the SEM as follows: 
Let the latent variable $y^{*}$ be linearly determined by a vector of observable exogenous variables: X. I have the following structural model, which assumes that the relationship between the exogenous variables and the latent variable is linear.

$\mathrm{y}^{*}=\boldsymbol{\alpha}^{\prime} \mathbf{X}+\varepsilon$

In the present analysis, the latent variable $\mathrm{y}^{*}$ is bargaining power and $\mathbf{X}=\left\{\mathrm{x}_{1}, \mathrm{x}_{2}, \ldots, \mathrm{x}_{\mathrm{k}}\right\}$ corresponds to a host of individual and institutional attributes of the respondent and $\varepsilon$ is the disturbance.

The latent variable in turn affects a vector of observable endogenous variables $\mathbf{Y}=$ $\left\{\mathrm{y}_{1}, \mathrm{y}_{2}, \ldots, \mathrm{y}_{\mathrm{m}}\right\}$, which in this case are the well-being outcome variables, subject to errors $\mathbf{u}=\left\{\mathrm{u}_{1}\right.$, $\left.\mathrm{u}_{2}, \ldots, \mathrm{u}_{\mathrm{m}}.\right\}$. It is assumed that the errors are mutually independent, have means equal to 0 and are uncorrelated with the exogenous variables. The observable endogenous variables may also be directly influenced by some of the observable exogenous variables. We have the measurement model, depicting the relationship between the exogenous variable, the latent variable, and the endogenous observed variables.

$\mathbf{Y}=\boldsymbol{\beta} \mathbf{y}^{*}+\boldsymbol{\gamma} \mathbf{X}+\mathbf{u}$

Thus I have a scalar $\mathrm{y}^{*}$ and set of vectors $\mathbf{Y}=\left(\mathrm{y}_{1}, \mathrm{y}_{2}, \ldots, \mathrm{y}_{\mathrm{m}}\right)$, which correspond to the set of well-being outcome variables, $\mathbf{X}=\left(\mathrm{x}_{1}, \mathrm{x}_{2}, \ldots, \mathrm{x}_{\mathrm{k}}\right)$ : the individual, institutional, and occupational attributes, $\boldsymbol{\alpha}=\left(\alpha_{1}, \alpha_{2}, \ldots, \alpha_{k}\right)$ : the coefficients corresponding to the equation for the latent variable, $\boldsymbol{\beta}=\left(\beta_{1}, \beta_{2}, \ldots, \beta_{\mathrm{m}}\right)$ : the coefficients corresponding to the outcome variables, and $\gamma=\left(\gamma_{1}, \gamma_{2}, \ldots, \gamma_{\mathrm{m}}\right)$ : the coefficients corresponding to the direct relationship between the exogenous observed variables and the endogenous variables.

The vector $\boldsymbol{\beta}$ corresponds to the underlying relationship between the latent bargaining power and observed well-being outcomes and is interpreted as the magnitude of expected change 
in the observed variable (the well-being outcomes) due to a unit change in the latent variable (bargaining power). It is necessary to assign a scale to the latent variable to be able to interpret the coefficient. Typically, the latent variable is set to a scale equal to one of the indicator variables. I estimate $\boldsymbol{\alpha}, \boldsymbol{\beta}$, and $\boldsymbol{\gamma}$ using STATA software.

Some points of concern are noted here. Structural equation modeling assumes components of vector $\mathbf{Y}$ to be continuous. However, as I will discuss later, our outcome variables are a mix of cardinal and continuous variables, and this may have implications on the inference. I hypothesize that there exists a latent continuous counterpart of the categorical variables where the latent maps one to one with the observed categorical variables (Di Tommaso et al. 2009). The second concern is that the standardized estimation uses maximum likelihood estimator, which assumes the joint distribution between $\mathbf{Y}$ and $\mathbf{X}$ to be multivariate normal. This may be restrictive in our case (Muthén 1984). STATA allows for flexibility in estimation by using a generalized structural equation model (GSEM) where I can estimate for categorical outcome variables using quasi maximum likelihood, and the assumption of normality is handled by adjusting the standard error (StataCorp 2013). However, the disadvantage with a GSEM is that I cannot test for the goodness of fit. Further, a GSEM does not allow us to obtain standardized coefficients, which are crucial for interpretation of the model. I have separately run both a SEM and GSEM as both have some advantage over the other and compare the estimates as robustness check. However, I will only report the results from the SEM, as the GSEM results did not provide any additional information to what I have from the SEM. The GSEM results are available on request. 


\section{VARIABLES}

Following the model specification it is crucial to identify the observed exogenous and endogenous variables of the model. To reiterate, the exogenous variables are the individual, occupational, and institutional characteristics and factors like age, skills, assets, occupational status, and so on, which determine and constrain the endogenous well-being experiences of the individual, including her capacity to make decisions, mobility, and retaining earnings. The exogenous characteristics affect the endogenous well-being variables both directly and indirectly through an unobserved individual characteristic, which I call the bargaining power.

\section{Exogenous variables}

The exogenous variables indicate the individual, institutional, and occupational resources available to the individual.

Individual characteristics: These include age and attractiveness of the sex worker, ${ }^{7}$ her skills, including her level of education and whether she has children (dummy variable). Age of the sex worker was found to be significantly correlated with the number of years spent in the trade. ${ }^{8}$ To avoid collinearity I have only included number of years spent in the trade (continuous variable), as it includes both an indication of age and experience of the sex worker, both of which are individual characteristics that are crucial for the determination of her bargaining power. Education has been reduced to a single dummy variable - educated (secondary school or more, dummy variable). I have also included the log of rate per short term sexual service 
provided as an exogenous variable as it may indicate the sex worker's desirability in the market and may be a proxy for her attractiveness and skills in the trade. ${ }^{9}$ It may also point toward how much of individual monetary resources the sex worker may access.

Occupational characteristics: Whether the sex worker was trafficked in the trade and whether she lives in the brothel are both occupational characteristics that may distinguish her position in the brothel vis-à-vis others in the trade, and consequently influence how much bargaining power she has and her well-being outcomes. A sex worker who is trafficked in the trade may be expected to have low bargaining power, at least to start, and the bargaining power may grow over time. Women who live in the brothel (as opposed to those who come in for work but return to a different location of residence at the end of the day) may on the one hand be less susceptible to institutionalized violence in the trade and have more community and family support outside the trade, but they may have less opportunity to build networks within the trade.

Institutional Characteristics: A sex worker's institutional characteristics would include her marital status (in our model, the dummy variable married), her caste and religious affiliations (the dummy variable Hindu high caste),${ }^{10}$ and her access to organizations and collectives that operate (the categorical variable Involvement with collectives). I consider marital status as an institutional characteristic (rather than individual characteristic) because for a sex worker, marriage is often seen as a separate and mutually conflicting institution to their trade. For the sex worker, marriage comes with a set of norms and regulations that are often at odds with the requirements of the trade. Thus, the effect of marital status on bargaining power is institutional, rather than individual. Involvement with collectives that work in close proximity to the trade may be seen as another crucial institutional characteristic and a determinant of the bargaining power of the sex workers. Since much of the information was gathered with the help of 
organizations working in Kolkata and Delhi, the data is biased against those in the trade who have no support from organizations. However, even within the information collected, there is a range of degree of involvement with collectives. While many sex workers may only be nominal members of the collective, some were more active members. Based on their involvement with the collective I have given them a ranking from 0 to 4 . A rank of 0 is given to sex workers who are either not aware or not members of any collective. A rank of 1 is given to those who are only nominal members. A rank of 2 is given to those who are more than nominal members and participate in rallies or protest marches or in campaigns for the cause. A rank of 3 is given to those who are "peer" workers or are members of the organization who are involved in implementation of the collective's campaigns (usually health related) among the sex workers. Finally, a rank of 4 is given to higher involvement, often in the decision-making as well as organizational roles in the collective. The higher the rank, the greater is the involvement with the collectives, and the higher the expected benefits from the operation of collectives in the locality. Sample statistics of the exogenous variables are presented in Table 1.

(Table 1 here, one page)

\section{Endogenous variables}

Two types of endogenous variables will be considered here, and each type will correspond to a different kind of bargaining power. I will first consider a set of endogenous variables that I call objective indicators of well-being. These will include outcomes including decision making, mobility, financial agency, and the capacity to retain earnings. ${ }^{11}$ These variables are considered to be the manifestation of a latent variable that I will call objective bargaining power. This set of 
variables will be distinguished from another set of endogenous variables, which I call self-

perceived or subjective indicators of well-being. The self-perceived indicators correspond to how the sex workers themselves rate their bargaining power, and these indicators will be the manifestation of what I call the subjective bargaining power. The distinction between the two latent bargaining variables gives us the opportunity to compare the sex worker's actual bargaining position to what she perceives her bargaining position to be. The understanding behind the differentiation is that perception of bargaining may be affected more by institutional factors than the actual bargaining.

Objective bargaining power

Decision making: In the dataset, there are six ordinal, self-reported variables that represent decision making. The respondent was asked about her decision-making capacity regarding 1) how many customers she had to provide services to, 2) her children's future, 3) clothes she wears at work, 4) her finances, 5) use of condoms with customers, 6) use of condoms with partners. The responses were in the form of self, joint (with one or more other agent including madam, pimp, customer, partner or husband, or family member), and other (including madam, pimp, customer, partner or husband, or family member). For every question, a sex worker who indicated making a decision by herself was seen as a positive outcome and was given a point of +1 . Joint decision making and no response were given 0 (as it is not necessarily negative, but does not indicate positive agency of the sex worker). Someone else making the decision was given a point of -1 as that has negative indication on the agency of the sex worker. The decision- 
making variables can broadly be categorized into variables that represent 1) decision making in the brothel (decisions regarding number of customers, attire, and condom usage with customers who are not regulars or partners), and 2) decision making regarding other aspects of life, especially the household (decisions regarding the future of children, finance, condoms with partners or other customers). For the SEM, I generate variables: ability to make decisions regarding work by oneself and ability to make decisions regarding nonwork aspects by oneself, with equal weights to each of the underlying decision-making variables (each of these variables takes values between -3 to +3 ). The percentage of sample in each category is presented in Table 2. A higher frequency of sex workers seems to be able to make decisions (on their own) regarding work as opposed to decisions regarding other aspects. The capacity to make decisions (by oneself) regarding finances and condom use with partners or regular costumers is particularly low (with only 15.0 percent and 26.3 percent respectively being able to make decisions by themselves). A sex worker with high (latent) bargaining power may be expected to be able to make more decisions by herself.

Mobility: Another outcome or indicator variable of interest may be mobility. This would directly be an indicator of "bodily integrity" in Nussbaum's list of capabilities. While a number of studies suggest that sex workers, especially those coerced into the trade, face very restricted mobility, it is quite likely that sex workers operating under such circumstances would not have been allowed to talk to the surveyors who conducted the present field study. However, though the respondents in the present study had mobility within the red light area (there was indication that most of them were not physically tied or bonded to the brothels), they faced restricted mobility with regard to going outside the city, especially to their hometowns, as well as with regard to participation in local events and meetings. This restriction was more a result of stigma 
associated with the trade, as well as because of concerns over personal safety. Summary statistics for the mobility variables are also presented in Table 2. Except in the case of "mobility to go to cinema on their own or with friends (not clients)," more than 60 percent of women said "yes" to all the other mobility variables. I reduced the five mobility variables (mobility to visiting hometown, to participate in local events, to participate in political events and meetings, to go to cinema, and to access hospitals) to a single variable that I call 'overall mobility', with equal weights to the underlying variables. The variable takes values between 0 and 5 , with the value 0 corresponding to individuals who said "yes" to none of the mobility variables and 5 corresponding to individuals who said "yes" to all of them.

Agency (financial): An additional indicator of well-being can be whether the respondents feel they are able to have a bank account in their own name and whether they can borrow money to start their own business. While these aspects may not directly indicate whether the respondent faces coercive restrictions to mobility, they may indicate agency based on various other factors. Thus I have two agency variables (“Agency to open bank account" and "Agency to borrow money to start business"), both of which are binary variables.

Retaining earnings: Retained earnings as an outcome variable indicates how much of her earnings the sex worker is able to keep. This is an indicator of the bargaining power of the sex worker in the trade and points toward the transactions costs faced by her in the trade vis-à-vis other agents. ${ }^{12}$ Proportion of earnings retained is a continuous variable that can take values between 0 and 1 . A value equal to 0 represents a situation where the sex worker has to forego all of her earnings to the brothel managers, while that of 1 indicates that she gets to keep all that she earns. What she has to forego can include charges for the brothel or rent, costs of pimp, bribes to authority, and in some cases cost of food. Summary statistics are presented in Table 2. On 
average, a sex worker would retain 77 percent of her earnings, and 23 percent would go to the brothel where she works.

(Table 2 here, half page)

\section{Subjective bargaining power}

In what follows, I look at what the sex workers perceive their bargaining and agency to be. This analysis is based on a set of six statements from the questionnaire in which the sex workers were asked to give a ranking of 1 to 5 to each statement, with 1 corresponding to strongly agree and 5 corresponding to strongly disagree. The questions and the responses are summarized in Table 3 . The latent variable subjective bargaining power is interpreted as an unobserved individual characteristic that establishes the sex worker's perceived bargaining power and manifests in the form of the subjective bargaining outcomes summarized in Table 3. High perceived bargaining power (latent) can be expected to correspond to high subjective bargaining outcomes.

(Table 3 here, half page)

\section{ESTIMATION RESULTS}

As mentioned earlier, I have modeled both objective and subjective bargaining power using an SEM. I reported the standardized coefficients of the SEM estimated using maximum likelihood method. Standardized coefficients, which give the change in units of standard deviation of the dependent variable for one standard deviation unit change in the independent variable, is 
preferred over normal coefficients because the former allows us to compare the coefficients in size when the variables have different measurement units (Krishnakumar and Ballon 2008).

\section{Objective bargaining power}

Table 4a describes the role of latent variable objective bargaining power in determining wellbeing outcomes of the sex worker. One additional standard deviation unit of years spent in the industry and involvement in NGOs and collectives increases objective bargaining power by about a third standard deviation unit of bargaining power. Living in brothels has a negative and significant effect on objective bargaining power. Contrary to expectation, individual and institutional factors like religion and caste, marital status, children, and level of education do not influence objective bargaining power. All of the well-being outcome variables are significantly affected by the latent bargaining power variable, indicating that all of the well-being variables are affected by the individual's occupational factors via their bargaining power. Of the wellbeing variables, bargaining power seems to affect decision making at work the most, with a standardized coefficient of 0.761 . Objective bargaining power seems to affect the agency variables the least, with one standard deviation increase in objective bargaining power resulting in 0.281 and 0.255 standard deviation increases, respectively, in agency to open bank account and agency to borrow money for business.

(Table 4a here, one page) 


\section{Direct effects}

Individual, institutional, and occupational factors may also directly influence the well-being outcomes of the sex worker. To get an indication of which exogenous variables may directly affect the endogenous well-being outcomes and to ensure a better fit of the model, I used modification indices to free parameters and add paths from some of the exogenous variables to the endogenous well-being outcomes. The paths added correspond to Table $4 \mathrm{~b}$. Individual and institutional factors seem to directly affect outcome variables more significantly than having an indirect effect via the bargaining power variable. Being married positively and significantly affects the ability to make decisions regarding work, and having children has a positive and significant effect on decisions that are not linked with work. Being Hindu and of higher caste positively and significantly affects agency to borrow money for business. These results may indicate that there are norms relating to the institution of marriage, having children, and being Hindu and of higher caste that override the stigma associated with sex work, thus directly affecting the individual's well-being without having to enter her capacity to negotiate or her bargaining power. Log of rate per short term sexual services provided has negative effect on the amount of money the sex worker is able to retain but positively influences her overall mobility.

(Table $4 \mathrm{~b}$ here, one page)

The value of chi-squared in this model is 0.0937 . This value together with the comparative fit index of greater than 0.90 and Root Mean Square Error of Approximation (RMSEA) of less than 0.8 indicates that the model has a satisfactory fit (Hair et al. 2009). 


\section{Subjective bargaining power}

In Table 5 I report the structural model for subjective bargaining power. Subjective bargaining power differs from objective bargaining power in the sense that it corresponds to a set of outcomes that measure what the sex worker perceives her bargaining to be. Only involvement with NGOs continues to be significant, indicating that involvement with NGOs improves both the actual as well as perceived bargaining power of a person. Interestingly, unlike in the case of objective bargaining power, marital status and rate of sexual services provided are positively and significantly related to the latent bargaining power, and being Hindu high caste is negative and significant. These results indicate that being married and being attractive, both seen as positive characteristics, may help sex workers perceive themselves as better at bargaining than they actually are. Moreover, while being a high caste Hindu entails adherence to more strict gender norms and consequently links to greater stigma related to sexuality and sex work, on the one hand, historically, membership within these castes was linked to ownership of land and property and hence more affluence. This may indicate that sex workers who are in this category perceive themselves worse off because they are comparing their position to other members from their caste background and hence perceive themselves to have lower bargaining power than they actually have (in terms of well-being outcomes). Subjective bargaining power significantly affects the sex worker's perceived ability to deal with problems with madams and violent customers, and her ability to deal with sudden trouble in the trade. However, it does not affect her perception of whether she is able to move to a different profession. Furthermore, the standardized coefficients corresponding to dealing with madam and violent customers $(0.850$ and 0.965, respectively) is higher than the perceived ability to deal with sudden trouble in the trade. 
This result indicates that sex workers do not perceive increased bargaining power with an increase in ability to overcome emergency situations in the trade or ability to leave the profession. In the case of the subjective bargaining model, the chi-squared value is less than 0.05, which is the minimum requirement for acceptable fit. However, in case of small samples, the chi-square value may be sensitive, and I need to rely on other goodness of fit measures. Since the comparative fit index (CFI) and Tucker Lewis Index (TLI) are both greater than 0.90 and Root Mean Square Error of Approximation (RMSEA) is less than 0.062 I may still deem the model to have a satisfactory fit.

(Table 5 here, one page)

Following the estimations, I compute the factor score of our two latent bargaining power variables. Since the two latent variables do not have the same unit of measurement, they are not comparable unless they are normalized. ${ }^{13}$ Figures 2 and 3, respectively, show the distributions of normalized objective and subjective bargaining power. Objective bargaining power is skewed left, while subjective bargaining power is multimodal.

(Figure 2 and 3 here, one page in all)

The objective and subjective bargaining powers are weakly and positively correlated with a correlation coefficient of 0.246 . This is illustrated in Figure 4.

(Figure 4 here, half page)

CONCLUSION 
This study is in line with recent scholarship on sex work, which has moved from the "victim" imagery of sex work to questions of empowerment. Rather than limiting to well-being in terms of subjective indicators of happiness and positive emotions, or objective indicators of quality of life, I try to understand well-being as freedom to live a positive life. Well-being in this paper is understood as an outcome of empowerment, which in turn is a multidimensional concept that combines external individual, occupational, and institutional constraints with internal (to the individual concerned) capacity to bargain, and manifests in the form of well-being outcomes. These well-being outcomes are comprehended in terms of "freedom" within capabilities approach and correspond to the ability to live a full social and political life with human functionings including the capacity to make one's own decisions, live a life free from violence, freedom of mobility, dignity, and so on.

To this effect, the study has identified the idea of bargaining power as a latent in-between that indirectly links the individual, occupational, and institutional constraints faced by the sex worker to the well-being outcomes. In this study, the outcomes considered are capacity to make decisions, freedom of mobility, agency, ability to retain earnings, and absence of abuse. The choice of variables is influenced by literature on empowerment in general, but also specifically by the literature on sex work. However, the choice of variables has also been limited by availability of data and may have resulted in omitted variable bias.

Results indicate that some individual, occupational, and institutional variables have significant effect on bargaining power and, consequently, on the determination of well-being outcome variables. Specifically, involvement with NGOs and collectives seems to positively affect bargaining power. However, it should be noted that there are differences in what 
determines actual (objective) and perceived (subjective) bargaining. There are indications that stigma implicitly affects perceived bargaining power more than actual bargaining power.

There are two major limitations in this study. As mentioned earlier, it was not possible to interview sex workers who are presently facing abusive conditions or who have been trafficked into the trade very recently because of the coercive conditions under which they live. This results in sample selection bias due to the nonrandom nature of sampling. Therefore, I am not making any claims on generality of bargaining power among sex workers based on this study, as I am forced to omit the section of the population that may be faced with very low levels of bargaining power. The second limitation of the study is due to the measurement error in the data, as all the well-being outcomes correspond to responses by the sex workers. The exercise of differentiating between objective and subjective bargaining power may to a certain extent implicitly acknowledge this problem by recognizing bias toward the sex worker's own perception of her bargaining power.

Neha Hui

University of Reading - Economics

Whiteknights Campus Post Box 217 Reading Berks RG6 6AH, UK

email:‥hui@pgr.reading.ac.uk

\section{NOTE ON CONTRIBUTOR}


Neha Hui is a PhD scholar at the University of Reading. Her research focuses on the effect of bargaining power and stigma in informal sector gendered labour markets including that of sex work and domestic work.

\section{ACKNOWLEDGMENTS}

The author would like to thank three anonymous reviewers for detailed reviews that have greatly improved the quality of this work. The author would also like to thank Professor Uma Kambhampati and Dr. Marina Della Giusta for supervising this research and would like to acknowledge the generous funding by Commonwealth Scholarship Commission, which made this research possible. 


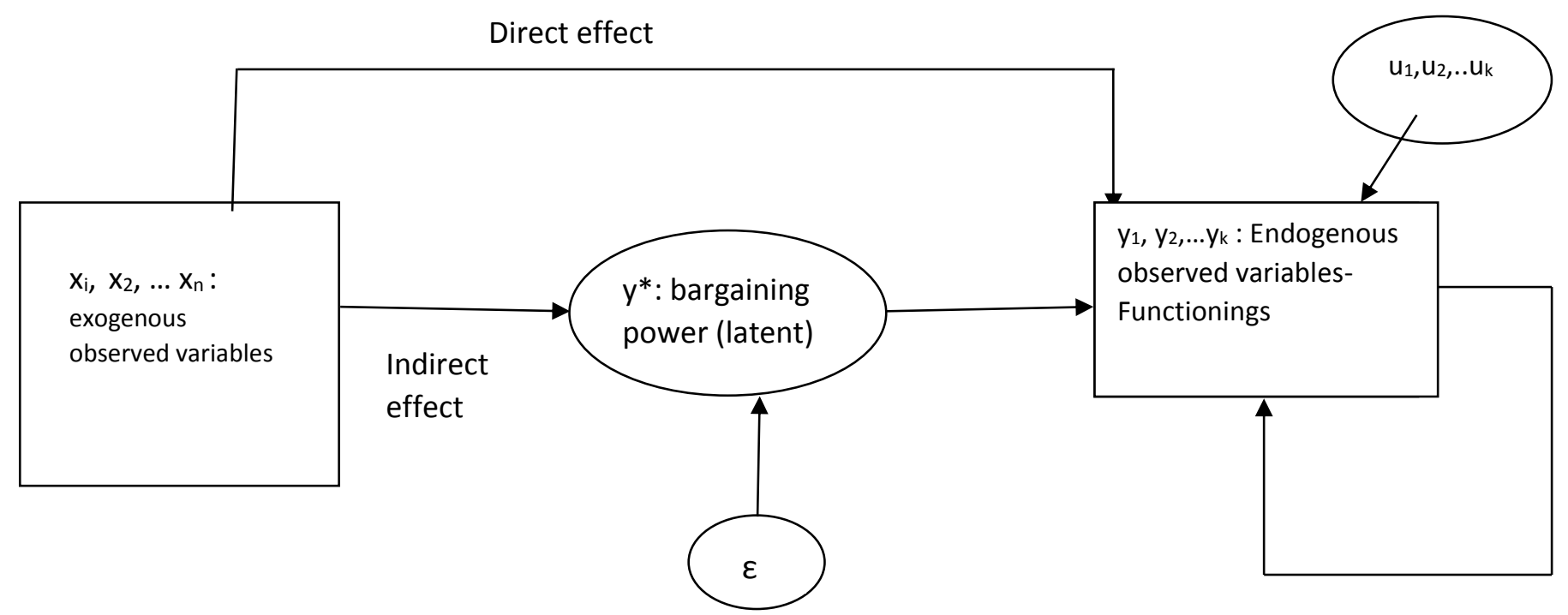

Figure 1 SEM with latent variable bargaining power 


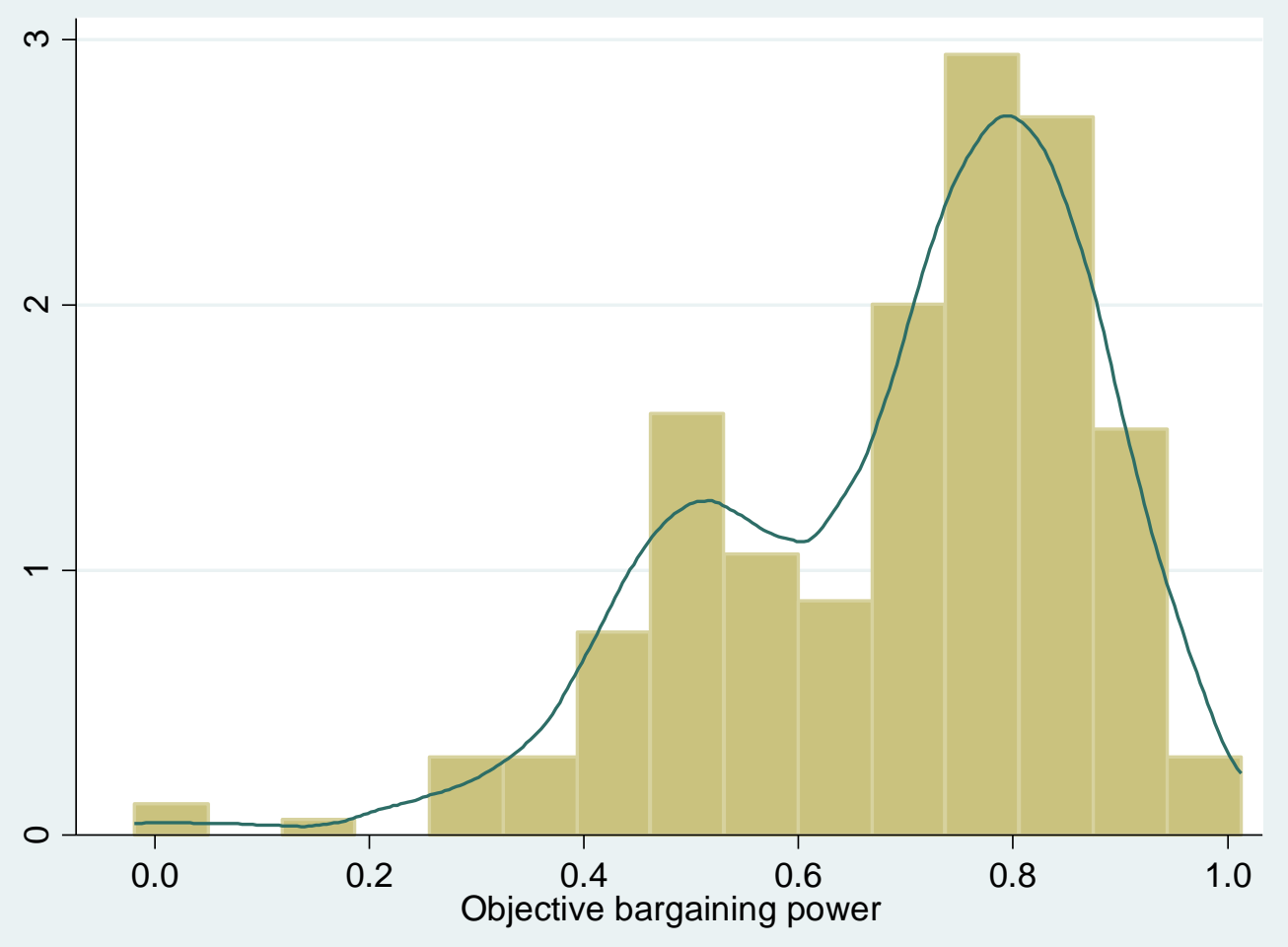

Figure 2 Histogram of objective bargaining power 


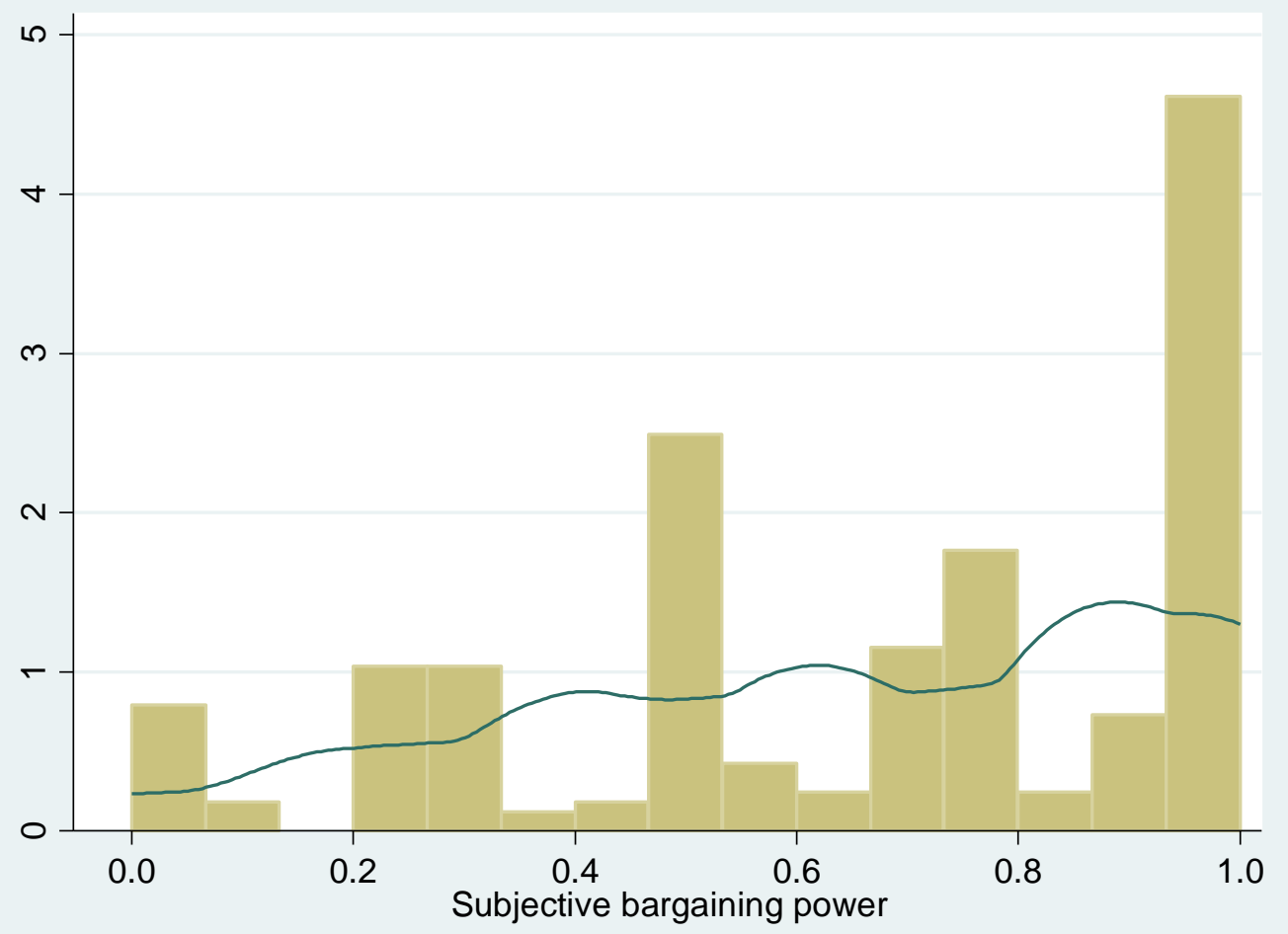

Figure 3 Histogram of subjective bargaining power 


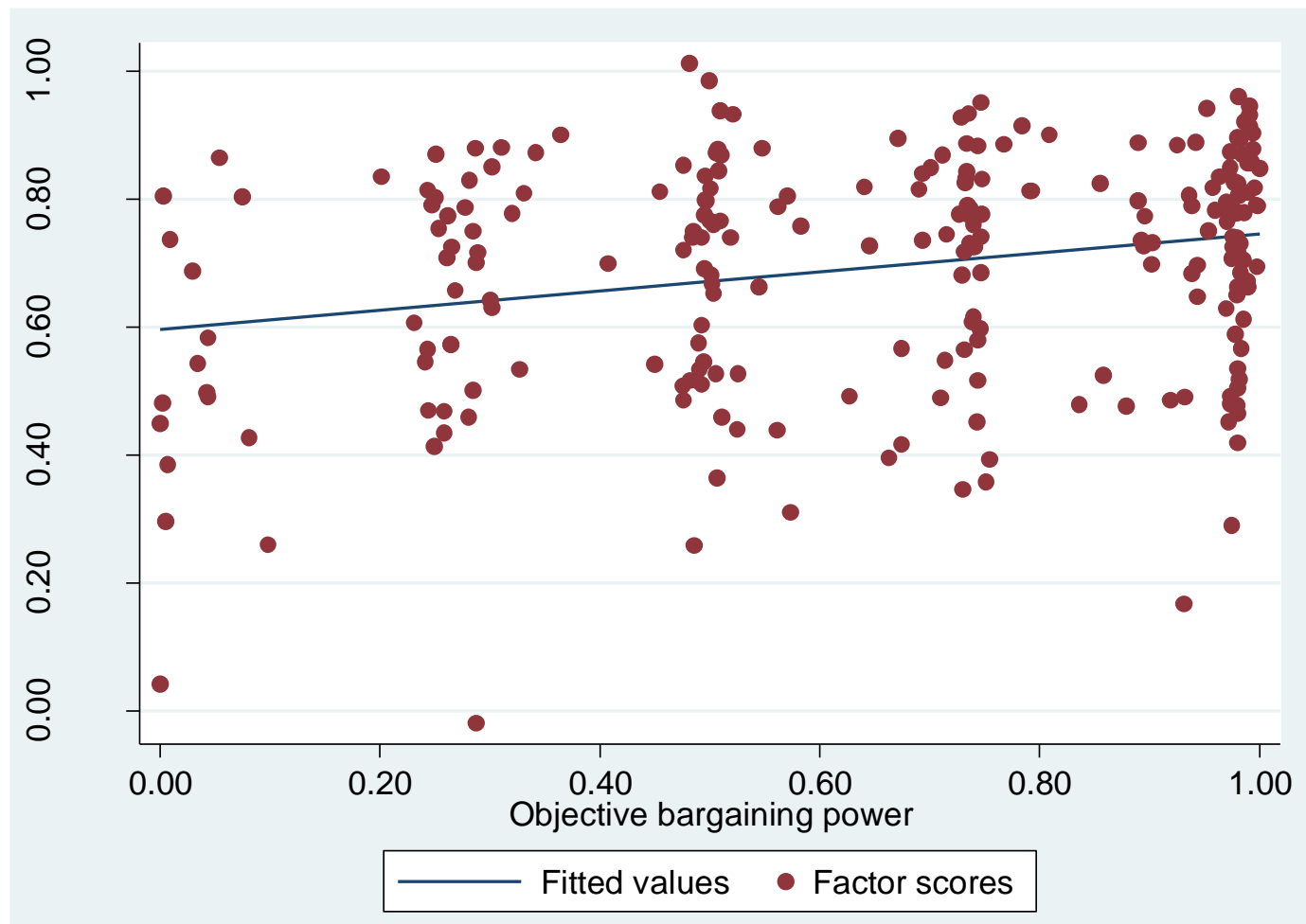

Figure 4 Scatterplot showing relationship between objective and subjective bargaining powers 
Table 1 Exogenous variables: Individual, institutional, and occupational attributes of women sex workers in Delhi and Kolkata

\begin{tabular}{|c|c|}
\hline Variables & Percentage \\
\hline \multicolumn{2}{|l|}{ Age group } \\
\hline $18-23$ & 17.46 \\
\hline $24-29$ & 23.81 \\
\hline $30-35$ & 27.38 \\
\hline $36-41$ & 15.87 \\
\hline $42-47$ & 6.75 \\
\hline$>48$ & 8.73 \\
\hline \multicolumn{2}{|l|}{ Education } \\
\hline No education & 56.22 \\
\hline Enrolled & 13.65 \\
\hline Finished primary & 8.03 \\
\hline Incomplete secondary & 15.26 \\
\hline Complete secondary & 5.22 \\
\hline Higher education & 2.81 \\
\hline \multicolumn{2}{|l|}{ Marital status } \\
\hline Never married & 11.9 \\
\hline Married & 28.17 \\
\hline Divorced/separated & 35.71 \\
\hline Widow & 7.54 \\
\hline With partner & 15.48 \\
\hline Not reported & 1.19 \\
\hline \multicolumn{2}{|l|}{ Children } \\
\hline Yes & 79.35 \\
\hline No & 20.65 \\
\hline \multicolumn{2}{|l|}{ Religion } \\
\hline Hindu & 70.45 \\
\hline Muslim & 25.91 \\
\hline Other & 3.64 \\
\hline \multicolumn{2}{|l|}{ Caste (among Hindus) } \\
\hline Scheduled caste & 39.66 \\
\hline Scheduled tribe & 5.03 \\
\hline General & 55.31 \\
\hline \multicolumn{2}{|l|}{ Involvement with NGOS/ } \\
\hline \multicolumn{2}{|l|}{ Collectives } \\
\hline None & 35.1 \\
\hline Only nominal members & 46.94 \\
\hline Only participations in rallies/events & 2.04 \\
\hline Peer worker & 12.24 \\
\hline $\begin{array}{r}\text { Supervisors/organizational committee } \\
\text { member }\end{array}$ & 3.67 \\
\hline \multicolumn{2}{|l|}{ Trafficked } \\
\hline Yes & 23.46 \\
\hline No & 76.54 \\
\hline \multicolumn{2}{|l|}{ Reside in brothel } \\
\hline Yes & 54.66 \\
\hline No & 45.44 \\
\hline
\end{tabular}




\begin{tabular}{|c|c|c|c|c|c|}
\hline Variable & Obs. & Mean & Std. Dev. & Min & $\operatorname{Max}$ \\
\hline $\begin{array}{l}\text { log of rate per short term sexual service } \\
\text { provided }\end{array}$ & 223 & 5.353 & 0.768 & 3.912 & 7.824 \\
\hline Years spent in the industry & 245 & 9.583 & 10.082 & 0 & 49 \\
\hline
\end{tabular}

Table 2 Endogenous variables: Indicators of objective well-being of women sex workers in Delhi and Kolkata

\begin{tabular}{|c|c|c|c|c|}
\hline Makes decisions by oneself (percentage of total sample) & Obs. & Self & Joint/ NA & other \\
\hline \multicolumn{5}{|l|}{ Ability to make decisions regarding work by oneself } \\
\hline How many customers & 247 & 74.49 & 1.21 & 24.29 \\
\hline Condom usage with one off customers & 247 & 88.66 & 0.81 & 10.53 \\
\hline Clothes she wears (at work or otherwise) & 247 & 94.33 & 1.21 & 4.45 \\
\hline \multicolumn{5}{|l|}{ Ability to make decisions regarding nonwork aspects } \\
\hline Finance & 247 & 14.98 & 1.21 & 83.81 \\
\hline Future of children & 247 & 76.02 & 1.53 & 22.45 \\
\hline Condom usage with partner/regular customer & 247 & 26.32 & 39.27 & 34.41 \\
\hline General mobility (percentage of total sample) & & Obs. & Yes & No \\
\hline Can visit hometown as frequently as she chooses & & 246 & 70.33 & 29.67 \\
\hline Can participate in local events & & 244 & 64.90 & 35.10 \\
\hline Can participate in meetings & & 245 & 63.30 & 36.70 \\
\hline Can access healthcare on her own & & 245 & 82.04 & 17.96 \\
\hline Can go to the cinema on her own or with friends (not clients) & & 244 & 48.16 & 51.84 \\
\hline Agency (percentage of total sample) & & Obs. & Yes & No \\
\hline Agency to open bank account & & 245 & 59.18 & 40.82 \\
\hline Agency to borrow money to start business & & 245 & 16.73 & 83.27 \\
\hline \multirow[t]{2}{*}{ Retains earnings } & & Std. Dev. & Min & Max \\
\hline & & 0.27 & 0 & 1 \\
\hline
\end{tabular}

Note: Sex workers who do not have children have been put in the category joint/NA.

Table 3 Endogenous variables: Indicators of subjective well-being being of women sex workers in Delhi and Kolkata (percent)

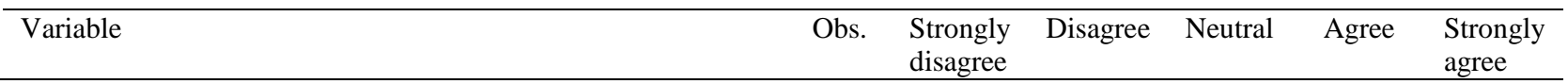




\begin{tabular}{llrrrrrr}
\hline I am able to deal with problems with my madam & 243 & 8.23 & 13.58 & 24.28 & 21.81 & 32.1 \\
I am able to deal with violent customers & 245 & 6.53 & 14.69 & 20.41 & 21.22 & 37.14 \\
I am able to deal with sudden crisis in the trade & 245 & 4.49 & 10.2 & 17.55 & 23.67 & 44.08 \\
I will be able to move to a different occupation if I so want & 244 & 20.9 & 16.39 & 6.97 & 12.7 & 43.03 \\
\hline
\end{tabular}




\section{Table $4 a$ SEM for objective bargaining power}

\begin{tabular}{ll}
$\begin{array}{l}\text { Estimates of the coefficients of latent objective bargaining power on the observed endogenous outcome variables } \\
\text { ( } \beta \text { in the model) }\end{array}$ & $\begin{array}{l}\text { Standardized } \\
\text { coefficient } \\
\text { (standard error) }\end{array}$ \\
\hline Variables & $0.761^{* * *}$ \\
\hline Ability to make decisions regarding work by oneself & $(0.074)$ \\
Ability to make decisions regarding nonwork aspects & $0.447^{* * *}$ \\
Retains earnings & $(0.068)$ \\
& $0.375^{* * *}$ \\
Overall mobility & $(0.073)$ \\
Agency to open bank account & $0.464 * *$ \\
& $(0.086)$ \\
Agency to borrow money for business & $0.281^{* * *}$
\end{tabular}

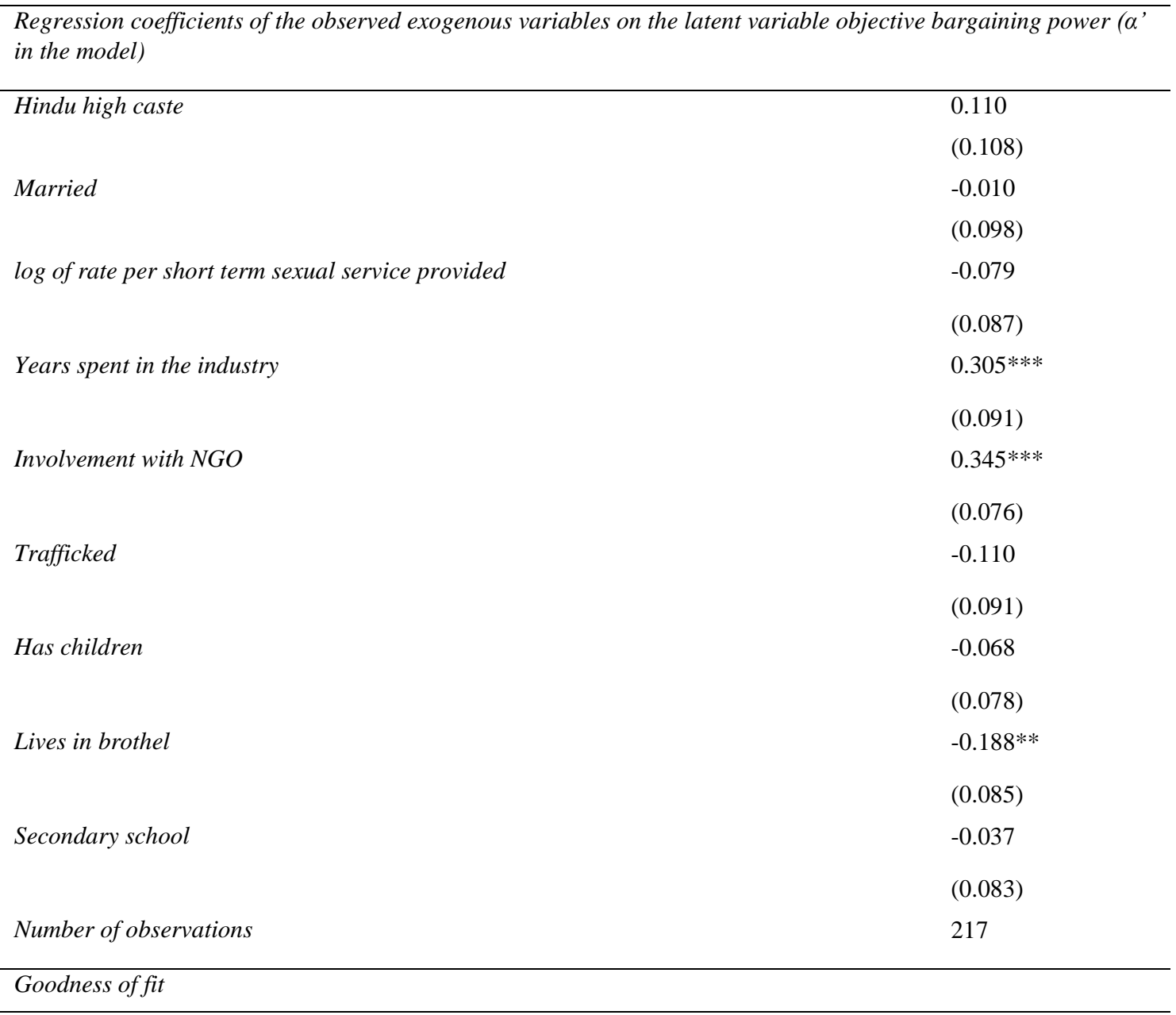




\begin{tabular}{lc}
\hline chi2 & 0.094 \\
CFI & 0.941 \\
TLI & 0.894 \\
RMSEA & 0.043
\end{tabular}

Notes: Standard errors in are in parentheses. $* * *, * *, *$ denote statistical significance at the 1,5 , and 10 percent levels, respectively.

Table $4 b$ Direct effect of relevant observed exogenous variables on endogenous outcome variables $(\gamma$ in the model)

\begin{tabular}{|c|c|}
\hline \multicolumn{2}{|l|}{ Ability to make decisions regarding work } \\
\hline Exogenous variables & $\begin{array}{l}\text { Standardized coefficient } \\
\text { (standard error) }\end{array}$ \\
\hline \multirow[t]{2}{*}{ Hindu high caste } & -0.124 \\
\hline & $(0.082)$ \\
\hline \multirow[t]{2}{*}{ Married } & $0.162 * *$ \\
\hline & $(0.071)$ \\
\hline \multicolumn{2}{|l|}{ Ability to make decisions regarding nonwork aspects } \\
\hline \multirow[t]{2}{*}{ Hindu high caste } & 0.447 \\
\hline & $(0.071)$ \\
\hline \multirow[t]{2}{*}{ Has children } & $0.252 * * *$ \\
\hline & $(0.060)$ \\
\hline \multicolumn{2}{|l|}{ Retains earnings } \\
\hline \multirow[t]{2}{*}{ log of rate per short term sexual service provided } & $-0.143 * *$ \\
\hline & $(0.066)$ \\
\hline \multirow[t]{2}{*}{ Years spent in the industry } & $0.215 * * *$ \\
\hline & $(0.068)$ \\
\hline \multirow[t]{2}{*}{ Lives in brothel } & $-0.144 * *$ \\
\hline & $(0.065)$ \\
\hline \multicolumn{2}{|l|}{ Overall mobility } \\
\hline \multirow[t]{2}{*}{ log of rate per short term sexual service provided } & $0.197 * * *$ \\
\hline & $(0.069)$ \\
\hline \multirow[t]{2}{*}{ Years spent in the industry } & -0.095 \\
\hline & $(0.082)$ \\
\hline
\end{tabular}




\begin{tabular}{ll} 
Trafficked & 0.173 \\
Lives in brothel & $(0.071)$ \\
& -0.042 \\
\hline Agency to open bank account & $(0.071)$ \\
\hline Involvement with NGO & $0.242^{* * *}$ \\
& $(0.070)$ \\
Lives in brothel & $0.113^{*}$ \\
& $(0.064)$ \\
\hline Agency to borrow money for business & \\
\hline Hindu high caste & $0.126^{*}$ \\
\hline
\end{tabular}

Notes: Standard errors in are in parentheses. ${ }^{* * *}, * *, *$ denote statistical significance at the 1,5 , and 10 percent levels, respectively. 
Table 5 SEM for subjective bargaining power

Estimates of the coefficients of latent Subjective bargaining power on the observed endogenous outcome variables ( $\beta$ in the model)

\begin{tabular}{lc}
\hline Variables & $\begin{array}{l}\text { Standardized } \\
\text { coefficient } \\
\text { (standard error) }\end{array}$ \\
\hline I am able to deal with problems with the madam & $0.850^{* * *}$ \\
$(0.028)$ & $0.965^{* * *}$ \\
I am able to deal with violent customers & $(0.024)$ \\
I am able to deal with sudden trouble in the trade & $0.669^{* * *}$ \\
I am able to move to a different profession if I so desire & $(0.040)$ \\
& 0.168
\end{tabular}

\begin{tabular}{|c|c|}
\hline \multicolumn{2}{|c|}{$\begin{array}{l}\text { Regression coefficients of the observed exogenous variables on the latent variable objective bargaining power ( } \alpha \text { ' in the } \\
\text { model) }\end{array}$} \\
\hline \multirow[t]{2}{*}{ Hindu high caste } & $-0.126^{*}$ \\
\hline & $(0.067)$ \\
\hline \multirow[t]{2}{*}{ Married } & $0.109 *$ \\
\hline & $(0.070)$ \\
\hline \multirow[t]{2}{*}{ log of rate per short term sexual service provided } & $0.203 * * *$ \\
\hline & $(0.0712)$ \\
\hline \multirow[t]{2}{*}{ Years spent in the industry } & 0.129 \\
\hline & $(0.078)$ \\
\hline \multirow[t]{2}{*}{ Involvement with $N G O$} & $0.201 * * *$ \\
\hline & $(0.068)$ \\
\hline \multirow[t]{2}{*}{ Trafficked } & 0.048 \\
\hline & $(0.077)$ \\
\hline \multirow[t]{2}{*}{ Has children } & -0.002 \\
\hline & $(0.067)$ \\
\hline \multirow[t]{2}{*}{ Lives in brothel } & -0.007 \\
\hline & $(0.0673)$ \\
\hline \multirow[t]{2}{*}{ Secondary school } & 0.088 \\
\hline & $(0.073)$ \\
\hline \multicolumn{2}{|l|}{ Goodness of fit } \\
\hline chi2 & 0.0037 \\
\hline$C F I$ & 0.941 \\
\hline$T L I$ & 0.913 \\
\hline RMSEA & 0.06 \\
\hline Number of observations & 220 \\
\hline
\end{tabular}


Notes: Standard errors in are in parentheses. ***,**,* denote statistical significance at the 1,5 , and 10 percent levels, respectively. 


\section{REFERENCES}

Akerlof, George and Janet L. Yellen. 1994. Gang Behavior, Law Enforcement, and Community Values. Washington DC:Canadian Institute for Advanced Research.

Basu, Kaushik. 1987. “Achievements, Capabilities and the Concept of Well-Being.” Social Choice and Welfare 4(1): 69-76.

Bérenger, Valérie and Audrey Verdier-Chouchane. 2007. "Multidimensional Measures of WellBeing: Standard of Living and Quality of Life across Countries.” World Development 35(7): 1259-1276.

Bhagat, R. B. and Soumya Mohanty. 2009. "Emerging Pattern of Urbanization and the Contribution of Migration in Urban Growth in India." Asian Population Studies 5(1): 520.

Blankenship, Kim M., Monica R. Biradavolu, Asima Jena, and Annie George. 2010. "Challenging the Stigmatization of Female Sex Workers through a Community-Led Structural Intervention: Learning From a Case Study of a Female Sex Worker Intervention in Andhra Pradesh, India.” Aids Care 22(S2): 1629-36.

Bollen, Kenneth A. 1987. "Total, direct, and indirect effects in structural equation models." Sociological methodology 17: 37-69.

Campbell, Catherine and Catherine MacPhail. 2002. "Peer Education, Gender and the Development of Critical Consciousness: Participatory HIV Prevention by South African Youth.” Social Science and Medicine 55(2): 331-345.

Census of India. 2011. New Delhi: Registrar General \& Census Commissioner of India. http://censusindia.gov.in/ 
Church, Stephanie, Marion Henderson, Marina Barnard, and Graham Hart. 2001. "Violence by Clients Towards Female Prostitutes in Different Work Settings: Questionnaire Survey." BMJ 322(7285): 524-25.

Clark, Andrew E., Paul Frijters, and Michael A. Shields. 2008. "Relative income, happiness, and utility: An explanation for the Easterlin paradox and other puzzles." Journal of Economic literature 46(1): 95-144.

Cornish, Flora. 2006. "Challenging the Stigma of Sex Work in India: Material Context and Symbolic Change." Journal of Community and Applied Social Psychology, 16(6): 46271.

Dandona, Lalit, Rakhi Dandona, Juan Pablo Gutierrez, G. Anil Kumar, Sam McPherson, Stefano M. Bertozzi, and Asci FPP Study Team. 2005. "Sex Behaviour of Men who have Sex with Men and Risk of HIV in Andhra Pradesh, India." Aids 19(6): 611-9

Day, Sophie E. and Helen Ward. 2004. Sex Work, Mobility and Health in Europe. London: Kegan Paul

Diener, Ed, and Eunkook Suh. 1997. "Measuring quality of life: Economic, social, and subjective indicators." Social indicators research 40(1-2): 189-216.

Kegan Paul, Della Giusta, Marina, Maria Di Tommaso, and Steinar Strøm. 2008. Sex Markets: A Denied Industry. Oxon: Routledge.

Di Tommaso, Maria L., Isilda Shima, Steinar Strøm, and Francesca Bettio. 2009. “As Bad as it Gets: Well-Being Deprivation of Sexually Exploited Trafficked Women.” European Journal of Political Economy 25(2): 143-62.

Easterlin, Richard A. 2004. "The economics of happiness." Daedalus 133(2): 26-33. 
Hill, Elizabeth. 2001. "Women in the Indian Informal Economy: Collective Strategies for Work Life Improvement and Development.” Work, Employment and Society 15(3): 443-64.

Gasper, Des and Irene van Staveren. 2003. "Development As Freedom v-v And As What Else?" Feminist Economics 9(2-3): 137-161

Gangoli, Geetanjali and Nicole Westmarland, eds. 2006. International Approaches to Prostitution: Law and Policy in Europe and Asia. Bristol: Policy Press.

Ghose, Toorjo, Dallas Swendeman, Sheba George, and Debasish Chowdhury. 2008. "Mobilizing Collective Identity to Reduce HIV Risk Among Sex Workers in Sonagachi, India: The Boundaries, Consciousness, Negotiation Framework.” Social Science and Medicine 67(2): 311-20.

Hui, Neha. 2012. "Adoption of a Transaction Cost Approach to Brothel-Based Sex Work: Case of GB Road, New Delhi, India.” Indian Journal of Labour Economics 55(3): 519-539.

Islam, Asadul and Russell Smyth. 2012. "The Economic Returns to Good Looks and Risky Sex in the Bangladesh Commercial Sex Market.” BE Journal of Economic Analysis and Policy 12(1): DOI: https://doi.org/10.1515/1935-1682.3059

Jöreskog, Karl G. and Arthur S. Goldberger. 1975. "Estimation of a Model with Multiple Indicators and Multiple Causes of a Single Latent Variable." Journal of the American Statistical Association 70(351): 631-9.

Kahneman, Daniel and Angus Deaton. 2010. "High Income Improves Evaluation of Life But Not Emotional Well-Being." Proceedings of the National Academy of Sciences 107(38): 16489-93. 
Krishnakumar, Jaya. and A. L. Nagar. 2008. “On Exact Statistical Properties of Multidimensional Indices Based on Principal Components, Factor Analysis, MIMIC and Structural Equation Models." Social Indicators Research 86(3): 481-96.

Krishnakumar, Jaya and Paola Ballon. 2008. "Estimating Basic Capabilities: A Structural Equation Model Applied to Bolivia." World Development 36(6): 992-1010.

Latkin, Carl A., D. Donnell, D. Metzger, S. Sherman, A. Aramrattna, A. Davis-Vogel, V. M. Quan, S. Gandham, T. Vongchak, T. Perdue, and D. D. Celentano. 2009. "The Efficacy of a Network Intervention to Reduce HIV Risk Behaviors Among Drug Users and Risk Partners in Chiang Mai, Thailand and Philadelphia, USA." Social Science and Medicine 68(4): 740-8.

Nussbaum, Martha. 2001. "Women and Equality: The Capabilities Approach” In Women, Gender and Work: What Is Equality and How Do We Get There?, edited by Martha Fetherolf Loutfi, 45-69.Washington DC: International Labour Office.

Martinetti, Enrica Chiappero. 2000. “A Multidimensional Assessment of Well-Being Based on Sen's Functioning Approach.” Rivista Internazionale di Scienze Sociali 108(2): 207-39.

Murgai, Rinku and Martin Ravallion. 2005. "Is a Guaranteed Living Wage a Good Anti-Poverty Policy?” World Bank Policy Research Working Paper 3640.

Muthén, Bengt. 1984. “A General Structural Equation Model with Dichotomous, Ordered Categorical, and Continuous Latent Variable Indicators." Psychometrika 49(1): 115-32.

Rooth, Dan-Olof. 2009. "Obesity, Attractiveness, and Differential Treatment in Hiring a Field Experiment." Journal of Human Resources 44(3): 710-35.

Sanders, Teela and Rosie Campbell. 2007. "Designing out Vulnerability, Building in Respect: Violence, Safety and Sex Work Policy.” British Journal of Sociology 58(1): 1-19. 
Scoular, Jane. 2010. "What's Law Got To Do With It? How and Why Law Matters in the Regulation of Sex Work." Journal of Law and Society 37(1): 12-39.

Sehnbruch, Kirsten. 2004. "From the Quantity to the Quality of Employment: An Application of the Capability Approach to the Chilean Labour Market.” Working Paper Center for Latin American Studies.

Sen, Amartya. 1983. Poverty and Famines: An Essay on Entitlement and Deprivation. Oxford: Oxford University Press.

-1999. Development as Freedom. Oxford: Oxford University Press.

—. 2001. "Work and Rights" In Women, Gender and Work: What Is Equality and How Do We Get There?, edited by Martha Fetherolf Loutfi, 33-45 Washington DC: International Labour Office.

—. 1997. Resources, Values, and Development. Cambridge, MA [ok?]: Harvard University Press.

—. 1985. "Well-being, agency and freedom: The Dewey lectures 1984." The Journal of Philosophy 82(4): 169-221.

Shannon, Kate and Joanne Csete. 2010. "Violence, Condom Negotiation, and HIV/STI Risk Among Sex Workers.” Journal of the American Medical Association 304(5): 573-74.

Solnick, Sara J. and Maurice E. Schweitzer. 1999. "The Influence of Physical Attractiveness and Gender on Ultimatum Game Decisions.” Organizational Behavior and Human Decision Processes 79(3): 199-215.

StataCorp. 2013. Stata: Release 13. Statistical Software. College Station, TX: StataCorp LP. 
Wojcicki, Janet Maia and Josephine Malala. 2001. "Condom Use, Power and HIV/AIDS Risk: Sex-workers Bargain for Survival in Hillbrow/Joubert Park/Berea, Johannesburg.” Social Science \& Medicine 53(1): 99-121.

\section{NOTES}

${ }^{1}$ Kolkata is the new name for the city in eastern India that was historically known as Calcutta.

${ }^{2}$ According to the Census of India 2011, the population of Kolkata is 14,112,536 and that of Delhi is $16,314,838$.

${ }^{3}$ All personal information that would allow the identification of any person(s) described in the article has been removed.

${ }^{4}$ Red light areas are zones exclusively relegated for brothel-based sex work.

${ }^{5}$ Literally translating to "half."

${ }^{6} 1$ Indian Rupee is equivalent to US $\$ 0.015$ (August 2016).

${ }^{7}$ Attractiveness is in terms of socially constructed ideals of beauty.

${ }^{8}$ The correlation coefficient between age and years spent in the trade in my data is 0.7 .

${ }^{9}$ Several studies have shown that there is a positive relationship between attractiveness and economic outcomes, especially income (Solnick and Schweitzer 1999; Rooth 2009), and particularly so in the case of sex work (Islam and Smyth 2012). I am using rate of services provided as a proxy as it is difficult to measure attractiveness, especially since it is a subjective concept and varies according to social and cultural perspectives. 
${ }^{10}$ The link between caste and prostitution in South Asia has been documented in the literature. Caste acts as an important factor resulting in entry of women into sex work, both directly and indirectly. Caste is often a hereditary mode of entry into the trade, especially for certain castes that specialize in providing sexual services. The Bedia community from Rajasthan (Agarwal 2014), Badi community in Nepal (Cox 1992), Nat community from north of India (Swarankar 2007), and Devdasi communities from the south of India (Omvedt 1983; Torri 2009) are examples of castes where women's hereditary occupation is sex work. Though women in many of such communities are expected to give consent about entering the trade, this is often only token consent as labor market alternatives are limited and age of entry in the trade (usually upon entry into puberty) is often too low to be able to provide informed consent. Caste is also an indirect route of entry into poverty (Gang, Sen, and Yun 2008), and poverty is one of the most important factors influencing entry into sex work (Cornish 2006).

${ }^{11}$ One well-being outcome variable that is conspicuously missing here is vulnerability to abuse. While a lot of literature focuses on violence faced by women in sex work (Church 2001; Sanders and Campbell 2007; Shannon and Csete 2010), it is important to note that respondents to the present survey reported violence that they had faced both within and outside the trade. Thirtynine percent of the sex workers reported to have faced physical (including sexual), mental, or psychological violence at home before joining the trade, and 21 percent reported to have faced violence in their previous occupation. The occupation of sex work is also characterized by violence at various stages. Thirty-two percent of the respondents faced violence at entry, and 23 percent of the respondents had to work as bonded sex workers (that is, a form of contract which entails that the sex workers work in brothels without any autonomy or access to earnings) at some point in their lives. Forty-two percent had faced one or more forms of violence in their 
career, including physical abuse, rape, and police violence. However, it was not possible to interview sex workers who were presently in abusive circumstances, as they would be less likely to give coercion-free responses. Furthermore, since the data is not over time, it was not possible to verify if there has been any change in the vulnerability to abuse. I have therefore not included abuse in the SEM but have elsewhere estimated the vulnerability to violence by using a logit model. The results are available on request.

${ }^{12}$ I define retained earnings as follows:

Proportion of earnings retained $=(\mathrm{R}-\mathrm{TC}) / \mathrm{R}$, where $\mathrm{R}=$ rate at which a sex worker provides sexual services, and $\mathrm{TC}=$ the amount she has to pay to the managers of the brothel for every time she provides services to a client.

${ }^{13}$ Following Krishnakumar and Ballon (2008), I use the following formula to normalize the score:

$y_{\text {normalized }}^{*}=\frac{y^{*}-\min }{\max -\min }$

Contact details

Cell: +447404536112 